\title{
8
}
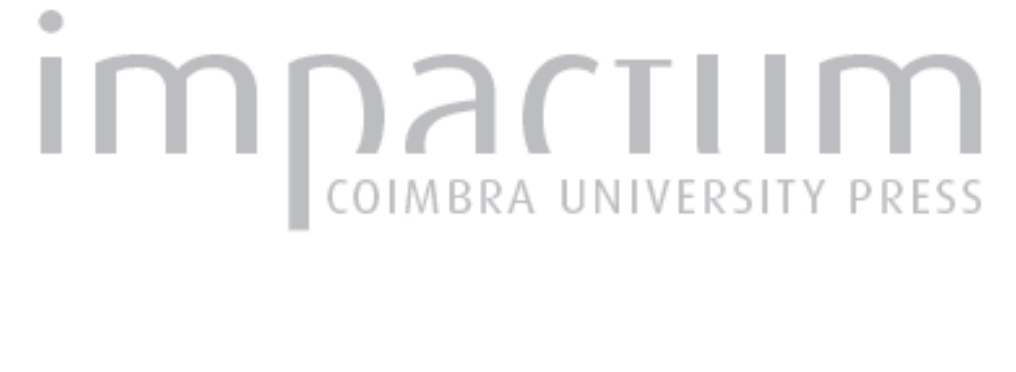

[Recensão a] Maria Teresa Rodrigues, Eduardo Lourenço. Hermeneuta do Imaginário

\author{
Autor(es): $\quad$ Umbelino, Luís António
} Publicado por: Faculdade de Letras da Universidade de Coimbra, Instituto de Estudos

URL

persistente:

DOI: $\quad$ DOl:http://dx.doi.org/10.14195/0872-0851_45_12

Accessed : $\quad$ 26-Apr-2023 00:31:10

A navegação consulta e descarregamento dos títulos inseridos nas Bibliotecas Digitais UC Digitalis, UC Pombalina e UC Impactum, pressupõem a aceitação plena e sem reservas dos Termos e Condições de Uso destas Bibliotecas Digitais, disponíveis em https://digitalis.uc.pt/pt-pt/termos.

Conforme exposto nos referidos Termos e Condições de Uso, o descarregamento de títulos de acesso restrito requer uma licença válida de autorização devendo o utilizador aceder ao(s) documento(s) a partir de um endereço de IP da instituição detentora da supramencionada licença.

Ao utilizador é apenas permitido o descarregamento para uso pessoal, pelo que o emprego do(s) título(s) descarregado(s) para outro fim, designadamente comercial, carece de autorização do respetivo autor ou editor da obra.

Na medida em que todas as obras da UC Digitalis se encontram protegidas pelo Código do Direito de Autor e Direitos Conexos e demais legislação aplicável, toda a cópia, parcial ou total, deste documento, nos casos em que é legalmente admitida, deverá conter ou fazer-se acompanhar por este aviso.

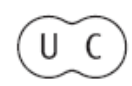




\section{REVISTA FILOSÓFICA DE COIMBRA}

vol. 23 - número 45 - março 2014

vol. 23 - número 45 - março 2014 Fundação Eng. António de Almeida

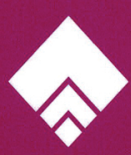


a biografia intelectual e o ambiente de Glocenius em Marburgo, passando de seguida ao exame central da 'ontologia' na história calvinista (mormente Timpler e Lorhard, além de Glocenius, evidentemente), ocupando-se, os dois capítulos da segunda parte, primeiro do que o A. chama "a codificação da ontologia na 'Isagoge in primam philosophiam' (1598), e depois do léxico da ontologia, a saber: abstractio, analogia, aliquid, possibilitas e res. Escusado será dizer, por conseguinte, que o A. da obra ora em recensão, com todo o mérito e competência, já ocupa um lugar indispensável, caso se queira fazer a história da ontologia. Tratar-se-á, no caso, de distinguir com precisão e acribia histórico-filológica o âmbito da ontologia do âmbito da metafísica, de informadamente assegurar a quota-parte que a escola jesuíta teve em toda esta metamorfose histórico-literária mas na qual a escola calvinista teve papel preponderante - assistiremos ao devir e à recepção alemã de Pedro da Fonseca, Bento Pereira ou Francisco Suárez -, finalmente, e já não seria mérito de somenos, de alterar a nossa narrativa sobre o debate metafísico jesuíta continental, e o da Schulmetaphysik até Kant com o alvitre de que, enquanto a lê, o leitor compreenderá nada mais nada menos do que a maneira como o Ocidente pensou e "inventou" a "realidade" como não coincidente com a realidade efectiva.

Mário Santiago de Carvalho

\section{Maria Teresa Rodrigues, Eduardo Lourenço. Hermeneuta do Imaginário Português, Fundação Eng. António de Almeida, Porto, 2012, 135 pp.}

O texto em apreço retoma o projecto de dissertação de Mestrado em "Hermenêutica, Linguagem e Comunicação", apresentada à Faculdade de Letras da Universidade de Coimbra, com o qual a autora recebeu o prestigiado prémio Doutor Miguel Baptista Pereira de 2007, instituído pela Fundação Eng. António de Almeida.

Trata-se de um trabalho com vários méritos e pontos de interesse dos quais, desde logo, se destacará o facto de se situar nos férteis lugares de fronteira onde, na diferença de perspectivas que sempre tornam mais profundos os pontos de encontro, a reflexão filosófica se fortifica.

Nesses lugares de fronteira reconheceu a autora ser possível meditar a que ponto "interpretar o sentido da nossa existência como povo assume em E. Lourenço uma natureza hermenêutica muito próxima da desenvolvida por P. Ricoeur nos seus estudos sobre problemas como a identidade pessoal, o mal ou o tempo, cuja clarificação exige a interpretação da linguagem simbólica através da qual ao longo do tempo o homem tem procurado esclarecê-los" (p. 23). Neste sentido se compreende que o ponto de partida do trabalho seja a "reflexão sobre Portugal" de um "hermeneuta heterodoxo" que partilha com o grande filósofo francês não apenas pressupostos fenomenológicos mas, igualmente, a valorização do literário como lugar de esclarecimento da existência humana. De facto, segundo a autora, os dois pensadores par- 
tilham a convicção de que a compreensão do humano não pode descartar a tradição que nos chega e nos toca através da linguagem e do muthus configurador do mundo que abre à refiguração orientadora da acção.

$\mathrm{Na}$ via de uma demonstração fundamentada deste acordo de fundo, estudará a autora algumas das categorias fundamentais da hermenêutica de P. Ricoeur, como sejam, por exemplo, as de "mundo do texto" (pp. 65 e ss), "identidade narrativa" (pp. 101 e ss), ou aquelas que são desenroladas pela rede conceptual que, no contexto de uma releitura do trabalho de Aristóteles sobre a mimesis da praxis, o filósofo de Valence medita através da tríade "pré-figuração", "configuração", "refiguração" (pp. 85 e ss). No contexto de tal estudo, a autora evidencia com acuidade que a reflexão ricoeuriana permite uma compreensão mais clara e sustentada da hermenêutica heterodoxa de Lourenço, em particular no que concerne ao modo como o filósofo português pensa a identidade cultural portuguesa a partir de um imaginário literário, mítico e simbólico próprio, que se deve entender como renovadamente apropriado de modo complexo. Neste ponto se encontra, parece-nos, um dos traços mais originais deste estudo.

É pois num colóquio alargado em redor da identidade, da memória, da linguagem e do imaginário que, na diferença de estilos, na distância de explicitações teóricas e de caminhos de reflexão, estes dois vultos do pensamento contemporâneo se "encontram". Como a autora anota de forma certeira, no fundo esse encontro é firmado no campo da investigação do sentido do homem e da sua história - sentido do homem e sentido da história que "só podem captar-se na grande digressão dos signos da humanidade depositados nas obras de cultura, sobretudo articulados e trazidos até nós pela literatura"(p. 129), que permanece esse enorme laboratório de possibilidades de sentido capaz de ordenar e significar a praxis temporal de múltiplas maneiras.

Luís António Umbelino

Vicki Müller-Lüneschloß: Über das Verhältnis von Natur und Geisterwelt. Ihre Trennung, ihre Versönung, Gott und den Menschen. Eine Studie zu F. W. J. Schellings "Stuttgarter Privatvorlesungen" (1810) nebst des Briefwechsels Wangenheim-Niederer-Schelling der Jahre 1809/1810, Frommann Holzboog, Stuttgart-Bad Cannstatt, 2012, 316 pp.

O livro de Vicki Müller-Lüneschloß, intitulado sobre a Relação da Natureza com o Mundo Espiritual, resulta de uma tese de doutoramento defendida na Universidade Ludwig-Maximilian de Munique em 2009, e apresenta um estudo sobre as denominadas Lições de Stuttgart (Stuttgarter Privatvorlesungen) que F. W. J. Schelling proferiu nessa cidade, em privado, de Fevereiro a Outubro de 1810 . 